\title{
INSIGHTS INTO THE COMPENSATION PRACTICES OF INDIAN CEMENT INDUSTRY: CERTAIN ISSUES AND CHALLENGES
}

\author{
N.Vijaya Santhi \\ Ph.D Scholar(FT), Dept. of Management, Dravidian University, Kuppam, A.P, India \\ Prof.G.L.Narayanappa \\ Dean, School of Commerce and Mgt. Dravidian University, Kuppam, A.P, India
}

DOI: https://doi.org/10.36713/epra3763

\begin{abstract}
The ' $Z E D$ ' cements and mineral industries limited was set up in the year 1955 in the most undeveloped region of earst while Andhra Pradesh. Subsequently, the company burgeoned as one of the largest cement manufacturing company in southern India. Later, in the year 2005-06 the company absorbed by M/s N.D GROUP OF INDUSTIRES. Since, its takeover, the chairman put abundant efforts to bring the industry into the peak elevation of the corporate world. For the last 64 years, the company is providing employment to the thousands of unemployed youth and illiterate workers in the region. The company started with initial production of $200 \mathrm{mts}$ per day and reached to $4000 \mathrm{TPD}$ after modernization. Now the original founder of the industry is no more now. His heriditatries are looking after the company.
\end{abstract}

\section{IMPORTANCE OF COMPENSATION MANAGEMENT}

In any manufacturing industry like cement, the employee employer relationship can be assumed as an exchange process of services where employees extend the services such as caliber, talent and professional skills for maximization of the productivity and as a compensatory measure the employees expect remuneration pocket of compensation and proper and scientific appraisal of the performance of employees. The timely extension of lucrative compensation for the employees have an important influence on their day to day life style, standard of living, feeling of security and stature. The other compensatory benefits such as (i) super annuation benefits; (ii) health parameters will also create vital foot print on the wellness of the employees. From the perspective of the managements of these cement industries, the concept of compensation includes extraordinary expenditure which needs to be regulated and the capital should engender sufficient revenue to meet the employees needs, enhance their skills, modify their attitudes and finally should improve organizational performance. An exclusive attempt is made in this research study on the compensation practices of a cement industry ${ }^{1}$.

In ever increasing corporate culture, the cement industries are functioning in an energetic and highly aggressive climate where the operational strategies of the business are required to change from time to time. The procedure followed for evaluation of the employees performance and compensation practices are two ways in the cement industries where can compile scientific competitive strategies to mesmarise and to keep back of employees with the organisation ${ }^{2}$. 
The level of compensation where the employees can be attracted to choose the particular organization for long-term employment, there only employees will have greater contentment and the way for achieving higher performance. The other compensation factor for retaining with the existing organization is the individual career ladder of the employed and what procedure the organizations are adopting for paying remunerative pocket of perks to the employees. Similarly, where the process of performance appraisal goes with dignity, respect and moral encouragement without any scope to illtreatment for the employees, such organisations will be preferred by the employees for long-term stay.

It is realized that the different compensation policies will hold direct impact on the retention of employees in a particular organization. Further, it is stated that, whenever the employees perceives that the compensation practices are vital and valuable for the career growth of the employees, they can be motivated positively and stay back with the 'ZED' company. The employees/workers will extensively be motivated and confidently enhances their skills and desirous of tendering their best cantillations to the organization. The working environment of any organization should provide challenging benefits and competitive advantages to the employees/workers,

\section{REVIEW OF LITERATURE}

Dyer (1985), In this study the author pointed out that the compensation policies are very strategic, which can impact upon the vision and mission of any organizations. Few, may write it off as another fade with less skeptical, as a strategic viewpoint on compensation. As a part of growing recognition, that the macro-organizational concerns have become focal parts of the study of human resource management. (3)

Kerr (1985), the author emphasized in his study on the compensation practices for general managers consisting of 35 items in all the aspects, which includes both the subjectivity and objectivity criteria of performance. In this paper the author focused on the time period and the value orientation of performance, clarity of the performance-reward relationship and the proportion of total compensation devoted to incentives. ${ }^{(4)}$

Sarah L. Fogleman, Robert A. Milligan, etl (1999), in their research paper they focused on the Employee Compensation and Job satisfaction in dairy farms with the reference to Northeast. Authors studied the correlation between various components of the compensation. This inference is consistent across the compensation spectrum. Total Satisfaction and all other satisfaction dimension, with regard to total compensation is positively correlated. (5)

Armstrong and Brown (2005), the authors stated in this paper that the compensation practice is included in the Human Resources Management approach of any organization. Its goals and strategies aim to keep focus on the long term problems relating to how the employees should be ranked for their performance and what are their target goals to achieve. Hence, it is integrated with the other functions of HRM with special emphasis on human resources development.(6)

Loomis (2008) has examined the compensation (salaries, bonuses, profit-sharing, stock purchase contribution) against the return on share holders' equity and found a least perfect correspondence, and moreover, highlighted the extreme cases of executives receiving relatively large increases in compensation during a period of deteriorating profitability for their firms. Loomis argued that the executive compensation in these times publicly held and the firms should be more directly tied to improve the firm performance. (7)

Zeljko Turkalj, Ivana Fosic and Davor Dujak, (2010), In this study the motivational factors of staff turnover in retail organizations, pointed out that the compensation practice is more powerful tool to impact on the organizations ethics and values. Though the employees, concentrates on the fair compensation but they don't take part in giving implication to the management of the organization with regard to compensation practices. Implications' regarding implementation and practices of compensations are given by the most affluent people in the organizations. ${ }^{(8)}$

Prof M. Rajah (2011),In his study the author came to a conclusion that the employee compensation determinants are vary from industry to industry and organization to organization and there is no focal method of compensation strategies. It is purely depends upon the nature of the organization. Authors implicated in this study that the compensation can be determined on the basis of several parameters such as job description, Job enrichment, Job profile and depends upon the operational nature of the firm. ${ }^{(9)}$

\section{SCOPE OF THE STUDY}

The scope of this study is confined to the compensation practices of employees/workers respondents of 'ZED' cements and mineral industries limited only. The outcomes of this study cannot be comparable to any other similar industries or organisations.

\section{OBJECTIVES} follows:

The specific objectives of the study are as

(i) To scrutanise the emerging practices of compensation management in ZED cements and minerals industries limited; To appraise the degree of satisfaction/dissatisfaction of employees/workers respondents towards 
the emerging practices of compensation management in ZED cement and mineral industries Ltd;

(iii) To investigate the grounds for the dissatisfaction of employees/workers respondents in ZED cement company towards the emerging practices of compensation management; and

(iv) To endeavor the viable ways and means to slaughter the animosity prevailed among the employee/worker respondents towards the emerging practices of compensation management in ZED cement company.

\section{RESEARCH METHODOLOGY}

The methodlogy consists of data collection from primary as well as secondary sources,. Through the survey method the first hand information was collected from 60 employees/worker respondents from the study unit.

\section{SMAPLE DESIGN AND SAMPLE SIZE}

A stratified random sampling techniques was followed and 25 percent of the core population/employees/workers from the study unit were selected as sample respondents which stood at a sample size of 60 members.

\section{ANALYSIS OF THE DATA}

The information extracted from primary sources was scientifically tabulated and analysed and several statistical tools such as (i) percentages; (ii) averages; (iii) Weighted mean scores; and (iv)ANOVA are calculated at appropriate levels and the inferences were drawn.

\section{THE LIMITATIONS}

i. The study is confined to only one cement industry which is located in southern India

ii. The size of sample is 60 only where the number is very meagre.

\section{RESEARCH FINDINGS}

1. The employees/workers are not given due importance and recognition while designing the compensation policies $(23.33 \%)$.

2. The management policies on compensation package are not based on the efficiency of employees/workers effectiveness in accordance with the essence of equity theory (11.66\%).

3. Ineffective compensation policy which is not resulting in potential advantages to the employees/workers and not at all enhancing either productivity or profitability of the organization. Also not conferring any advantages to the workers/employees either in monetary advantages or in promotional avenues $(30.00 \%)$.
4. The present compensation system does not includes the vital elements of compensation such as (i) motivating factors for employees; (ii) improving factors of the potentiality of employees/workers; and (iii) increasing of productivity enhancing skills of the employees/workers (26.66\%).

5. There is a negative and insignificant relationship between payment of compensation and job satisfaction. The organization is not at all paying much attention to this vital aspect $(8.33 \%)$.

\section{SUGGESTIONS}

1. Considerable participatory opportunity should be given to the employees/workers or their representatives while designing the compensation policies. So that the discontentment or dissatisfaction to be arised in this regard can be minimised.

2. While preparing the compensation policies, the efficiency and professional effectiveness of the employees should keep in mind and in accordance with the equity theory of essence; these compensation policies should be designed.

3. The proposed compensation policy should be able to confer potentional monetary and non- monetary advantages to the employees/workers as well as reasonable productivity and profitability to the management of ZED. The policy should also be able to create promotional avenues to the employees/workers.

4. The proposed compensation policy should also includes the vital elements of compensation such as (i) motivating factors of employees (ii) improving factors of the potentiality of the employees/workers; and (iii) increasing capacity of the productive skills of the employees/workers. So that the employees/workers can be motivated themselves without the influence of any external factors.

5. While designing the prudential compensation policy it is the responsibility of the management of ZED to create positive and significant relationship between the compensation and job satisfaction of the employees/workers. The management should give topmost priority to this vital aspect of compensation.

\section{REFERENCES}

1. John M. Ivancevich: Human Resource Management, Tata McGraw Hill, New Delhi, 2005, pp.8-9.

2. Anne M. Bogardus: Human Resources Jump Start, Sybex publishers, London, 2004,p.15. 
3. Dyer, Lee. (1985). Strategic human resources management and planning. In K.M. Rowland $\mathcal{E}^{\circ}$ G.R. Ferris (Eds.), Research in personnel and human resources management. Vol. 3 (p. 1-30).

4. Kerr, J.L. (1985). Diversification strategies and managerial rewards: An empirical study.

5. Harris, P. R. and Moran, R. T. (1996) Managing Cultural Differences, Houston, TX: Gulf.

6. Armstrong, M. and Brown, D. (2005). Relating Competences to pay: The UK Experience, Compensation and Benefit Review, 18(2); 2905-310.

7. Loomis (2008), Compensation includes salaries, bonuses, profit sharing, stock purchase contribution

8. Zeljko Turkalj, Ivana Fosic and Davor Dujak,Motivational Compensation A Factor In Staff Turnover In Retail Organizations. https://econpapers.repec.org/scripts/redir.pf? $u=h t t p \% 3 A \% 2 F \% 2 F$ wwrw.efos.unios.hr\% $2 F$ repec\%2Fosi\%2Fjournl\%2FPDF\%2FInterd isciplinaryManagementResearchVI\% 2FIMR6a23.pdf; $h=$ repec:osi:journl:v:6:y:201 o:p:264-274

9. Rosa Cintrón and Forrest Flaniken (2011), Performance Appraisal: A Supervision or Leadership Tool? International Journal of Business and Social Science Vol. 2 No. 17 wrwr.ijbssnet.com Pp 29-37. 